\title{
Study on the Overall Construction of Mountainous Town based on the Concept of The Sponge City
}

\author{
$\mathrm{JunMi}^{1}$, YulinLuo ${ }^{2}$ \\ ${ }^{1}$ Chongqing Radio \&TV University, Chongqing, 401520,China \\ ${ }^{2}$ Chongqing university of education , Chongqing, 400074,China
}

\begin{abstract}
The emergency and significance of the development and construction of sponge cities have become a national issue, and it is urgent to deal with irrational problems and disorganization emerged in the construction of sponge city. Due to the complexity of constructing sponge cities, the macroscopic town planning should be put in the first place, and controlling objects are made in accordance with cities' different characteristics. Then details in technologies in building sponge cities should be organize.
\end{abstract}

\section{INTRODUCTION}

With the extend of urban area, the impervious ground after "hardening" of roads, concrete floors, and public squares in the city have occupied a much natural green space, and their structures have destroyed the water cycle in nature. The scarcity of urban land also continues to invade natural lakes, wetlands and other natural "sponges" that can store water. This has caused urban water logging in China in recent years. It has also brought about a series of problems such as water pollution, water shortage, lack of water security, and disappearance of water culture. Governments at all levels have gradually recognized these problems in urban construction $^{[1]}$. In order to achieve harmony between urban development and nature and the environment respectively, The application of urban sponge technology has begun to receive the attention of many city builders, and a large number of engineering practices have been carried out throughout the country.

\section{The concept of sponge city}

Sponge city means that the city, like a sponge, has water absorption, water storage, filtration, buffering and regulation of large amounts of water. When it rains, it can be used to supplement natural water bodies, regulate river flow, and cleanse the water. It can also be used only after simple treatment ${ }^{[2]}$. Through the construction of the Sponge City, the destruction of the original natural aquatic ecology features and water ecological environment caused by urban development and construction activities will be minimized, and the city will be built into a "sponge" of natural accumulation, natural penetration and natural purification.

\section{Analysis of the demands for the construction of sponge city in mountainous towns}

\subsection{High pressure in urban water logging}

Sponge city is a sustainable ecological city whose construction is based on rainwater flood control. China has a vast territory. Different regions have their own natural and social characteristics. Among them, mountainous towns are typical complex cities. In order to successfully construct ecological rainwater systems in these towns, it is necessary to carry out site planning and optimization and layout of technical measures of sponge city in a targeted manner while fully understanding its characteristics. The new area which is still in the process of urban development and construction is likely to suffer from high intensity of urban water logging when rainfall is concentrated in such areas of the mountainous areas due to the failure to form a perfect urban drainage system and coupled with the characteristics of the floods in the mountains(Figure 1)

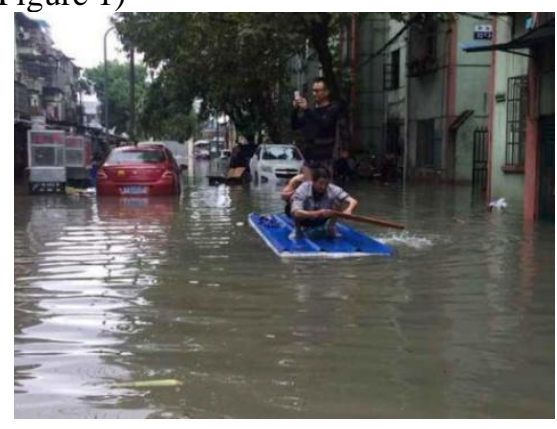

Figure 1 Urban water logging 


\subsection{High pressure in protection of water environment quality}

Although many urban water environment quality can basically maintain the natural state, the overall water quality is IV or above. However with the development and construction of cities, the surface area of impervious ground increases, and the risk of urban runoff source pollution increases, (Figure 2) as well as the increase of pressure in protection of water environment quality. The control of storm water runoff pollution is one of the main goals of the construction of a sponge city, which will help protect the quality of water environment.

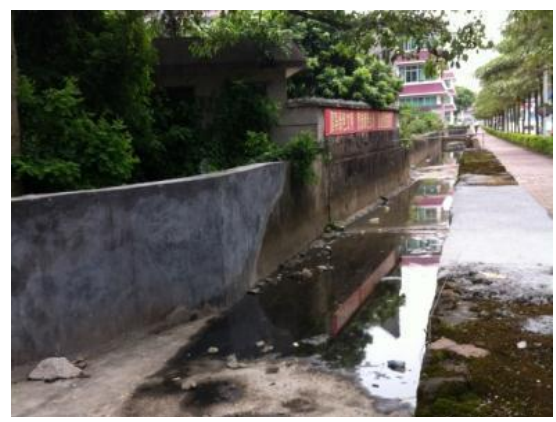

Figure 2 Pollution of urban rainfall runoff

\subsection{Protection and repair of city's blue-green carriers}

Two major carriers of the sponge city construction are the blue and green space of the city. Therefore, in the process of urban construction, the concept of sponge city construction should be fully integrated to protect the original ecological background as much as possible while increasing, the urban water surface space. Under the premise of the regular flood function of the river system, ecological construction of the coastline of the river system should be carried out as far as possible so as to avoid the occurrence of concrete pouring and the formation of a "three-sided light" channel.(Figure 3).

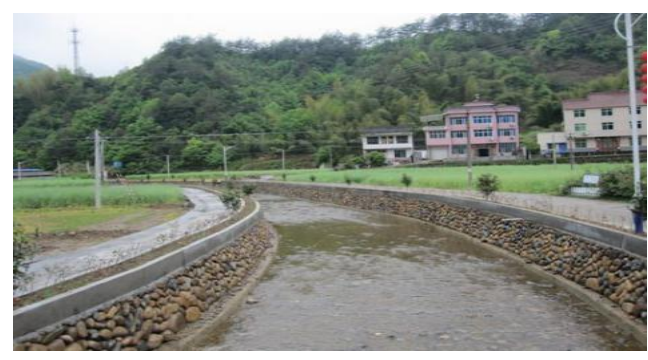

Figure 3 "Three-sided light” channel

\subsection{Use of rainwater}

In accordance with the basic ideas of the problem-oriented orientation of the old sponge city construction and the orientation of the new city, combining the status characteristics city constructors in mountainous towns should determine the main objectives of the sponge city construction are total runoff and control of runoff pollution, mitigation of the urban intrinsic risk, and protection and restoration of the water environment quality and blue-green ecological space, the use of rainwater.

\section{The structure of the planning and constructing of sponge city in mountainous towns}

\subsection{Factors of sponge city in mountainous towns}

Through the analysis of all the external features of urban landform and the surface morphology, as well as the causes and development trends of these features, we will judge and explore the forms and means of implementation in sponge space. Through the separation of geomorphological elements, the correlation and separation relationship of each element in the construction process of the sponge city was analyzed to further analyze the changes of the distributing pattern of precipitation and runoff and provide guidance for the construction of the sponge ecosystem.

\subsection{The control rate of annual total runoff}

The mainland is divided into five parts by The guidance to technologies in construction of a sponge cites, and the maximum and minimum limits of control rate $\alpha$ is given: district $\mathrm{I}(85 \% \leq \alpha \leq 90 \%)$, district $\mathrm{II}(80 \% \leq \alpha \leq 85 \%)$, district $\operatorname{III}(75 \% \leq \alpha \leq 85 \%)$, district $\operatorname{IV}(70 \% \leq \alpha \leq 85 \%)$ and district $\mathrm{V}(60 \% \leq \alpha \leq 85 \%)^{[3]}$.

The range of $\alpha$ should be determined according to the district that towns located, the control rate of annual total runoff. Considering various conditions such as the natural environment, urban location, planning concept, and economic development of the site, besides statistical analysis based on the daily rainfall data collected in recent decades, we can determine the control rate of annual total runoff and determine the corresponding designed rainfall.

\subsection{Determination of general control standard}

According to the relevant provisions in Code for Design of Outdoor Waste water Engineering (GB50014), the standard for drainage and flood control during the urban construction should be determined and the years of rainstorm without disasters should be designed ${ }^{[4]}$. According to the relevant provisions in standard for flood control (GB50201-2014), the standard for flood control should be determined on the basis of local urban planning and comprehensive planning for watercourse treatment, as well as in consideration of regional terrain features, flood features and circumstances for flood control. $^{[5]}$

\section{Analysis of sponge function zoning in mountainous towns}

In order to provide better protection for the urban sponge systems such as mountains, water, forests, fields, and lakes, the main directions and functions of the construction of the sponge city shall be defined, and the functional zone of sponge city shall be designated in the 
planning area.

\subsection{Factor analysis of functional zone}

\subsubsection{Evaluation of ecological sensitivity}

Ecologically sensitive areas are those areas that have special sensitivities to human production and living activities or have potential natural disasters, and are vulnerable to human-induced improper development activities and emerge ecologically negative effects. Urban development in the future must be based on urban and rural spatial development strategies so as to avoiding areas with high ecological sensitivities.

\subsubsection{Analysis of land use}

We shall find out the current situation for existing enterprises, institutions, buildings and structures within the scope of the land use, analyze a variety of factors such as land topography, geology.etc, form land use status and plan land layout.

\subsection{Function zoning}

According to the results of factor analysis in functional zone such as the assessment of ecological sensitivity, functional zone of aquatic ecology and the evaluation of land use, the regional space in planning area is divided into five major sponge functional zone.

\subsubsection{Natural sponge conservation zone}

The natural sponge conservation zone should have enough geographical area, which should be the ecologically sensitive area such as mountains and hills around the planning area. The characteristic of the land use is mainly high-density coverage area of natural vegetation .The main function of natural sponge conservation zone is ecological conservation. All types of development and construction activities should be strictly controlled within the region; the comprehensive treatment of the ecological environment should be strengthened; the diversity and stability of the ecosystem should be improved; and the conservation function of the large sponge system should be guaranteed.

\subsection{2 sponge buffer zone}

The main function is protection, but partial area can be properly developed after taking some measures. The layout of land use should be mainly ecological forest land, eco-agricultural land, and a small amount of construction land, with emphasis on the development of eco-tourism, eco-agriculture and other environment-friendly industries. The scale and intensity of development should be controlled to avoid the erosion for the buffer zone caused by excessive frequent construction activities.

\subsubsection{Aquatic ecology's protection zone}

The main function of aquatic ecology's protection zone is protection. And it strictly controls the scope of blue lines in aquatic area, establishes protection area of ecological function, protects and restores natural vegetation. We shall control water pollution, reduce water pollution load, and strictly limit industrial development that leads to water pollution and vegetation destruction.

\subsubsection{Sponge repair zone for construction}

The main function is sponge-based restoration. The sponge repair zone for construction is problem-oriented, using the current green space to build low-impact development facilities according to local conditions, reducing rainwater runoff at the source and controlling initial rainwater pollution.

\subsubsection{Sponge upgrading area}

The main function is sponge promotion. Priority should be given to the implementation of the blue-green space system and protection should be given to water-sensitive areas, besides we shall comprehensively use the measures such as seepage, stagnation, storage, net, use, and drainage according to scientific organization of rainwater confluence process, then we will comprehensively control pollution on runoff from aspects of source, process and terminal, cut peak of runoff and improve the quality of sponge city construction.

\section{Conclusion}

In 2015, in accordance with the requirements of the State Council, the Ministry of Finance, the Ministry of Housing and Urban-Rural Development, and the Ministry of Water Resources selected 16 cities to carry out projects for the construction of sponge cities. These cities have encountered some problems in the construction of the past two years and also summed up some successful experiences. These cities try in the first and continuously summary successful experiences. Other cities can conclude the construction model of sponge city that is suitable for themselves, although they are in different regions and different levels of development .According to the construction of sponge cities, we will achieve the goal that, by $2030,70 \%$ of the rainfall will be consumed and utilized on the spot in the $80 \%$ of the country's urban built-up areas.

\section{Acknowledgement}

Project Supported by Scientific and Technological Research Program of Chongqing Radio \& TV University(No.YB2017-02) 


\section{Reference}

1. Jun Mi, Yulin Luo. Study on Design Analysis of LID Facility in Sponge City[J]. Si Chuan Cement,2017(09):102.

2. Ministry of Finance, Ministry of Housing and Urban-Rural Development, Ministry of Water Resources. Announcement on Launching the Central Government's Support for Pilot Cities in Sponge City[EB/OL].http://www.mohurd.gov.cn/wjfb/20150 1/t20150115_220129.html,2015-10-13 .Yongping Nie.etc. Study and Analysis for the Cost of Utility Tunnel. Underground Space, 2004, 3 (24): 37-39.

3. Ministry of Housing and Urban-Rural Development of the People's Republic of China. Technical Guide for Construction of Sponge City - Construction of Rainwater System Developed in Low Impact (Trial)[Z],2014.

4. Ministry of Housing and Urban-Rural Development of the People's Republic of China. Code for Design of Outdoor Waste water Engineering (GB50014-2006) [Z],2016.

5. Ministry of Housing and Urban-Rural Development of the People's Republic of China. Standard for Flood Control (GB50201-2014) [Z],2014. 